\title{
King Vulture Sarcoramphus papa (Linnaeus, 1758) (Aves, Cathartidae) nesting in a manmade structure
}

\author{
Laís Petri ${ }^{1}$, Bárbara Heliodora Soares do Prado ${ }^{2,4}$, \\ Alexsander Zamorano Antunes ${ }^{3}$ \& Benedito Carlos de Oliveira ${ }^{2}$ \\ ${ }^{1}$ Universidade Federal de São Carlos - UFSCar, CEP 18052-780, Sorocaba, SP, Brasil \\ ${ }^{2}$ Estação Ecológica de Angatuba, Seção de Estação Experimental de Itapetininga - IF, \\ CP 143, CEP 18200-000, Itapetininga, SP, Brasil \\ ${ }^{3}$ Instituto Florestal - IF, Rua do Horto, 931, CEP 02377-000, São Paulo, SP, Brasil. \\ www.iflorestal.sp.gov.br \\ ${ }^{4}$ Corresponding author: Bárbara Heliodora Soares do Prado, e-mail: barbarahsprado@gmail.com
}

PETRI, L., PRADO, B.H.S., ANTUNES, A.Z. \& OLIVEIRA, B.C. King Vulture Sarcoramphus papa (Linnaeus, 1758) (Aves, Cathartidae) nesting in a manmade structure. Biota Neotrop. 13(2): http://www.biotaneotropica. org.br/v13n2/en/abstract?short-communication+bn04013022013

Abstract: The King Vulture Sarcoramphus papa (Linnaeus, 1758) is declining globally and it is listed as threatened with extinction in state of São Paulo, southeastern Brazil. Despite a recent increase in observations of this species, nesting records are scarce in the state. We report a nesting attempt on an observation tower at Estação Ecológica de Angatuba, southwestern state of São Paulo.

Keywords: Angatuba, breeding behavior, conservation, wooden tower.

PETRI, L., PRADO, B.H.S., ANTUNES, A.Z. \& OLIVEIRA, B.C. Urubu-rei Sarcoramphus papa (Linnaeus, 1758) (Aves, Cathartidae) nidificando em estrutura feita pelo homem. Biota Neotrop. 13(2): http://www. biotaneotropica.org.br/v13n2/pt/abstract?short-communication+bn04013022013

Resumo: O urubu-rei Sarcoramphus papa (Linnaeus, 1758) está em declínio globalmente e é listado como ameaçado de extinção no estado de São Paulo. Apesar do aumento recente de observações da espécie, os registros de nidificação nesse estado são escassos. Relatamos uma tentativa de nidificação do urubu-rei em torre de observação na Estação Ecológica de Angatuba, sudoeste do estado de São Paulo.

Palavras-chave: Angatuba, comportamento reprodutivo, conservação, torre de madeira. 


\section{Introduction}

The King Vulture is an iconic member of the Neotropical fauna, thanks to its size, color and natural rarity. Although not considered globally threatened, their populations are in decline, mostly due to habitat loss and poaching (BirdLife... 2012). Available population estimates suggest fewer than 50,000 individuals all over its original distribution area from Mexico to Argentina, and total number of mature specimens is less than 10,000 (BirdLife... 2012).

In the state of São Paulo, southeastern Brazil, the King Vulture is considered threatened with extinction and listed in the category "vulnerable" (São Paulo 2008). Even with increasing recent records in this state (Wikiaves 2012), there are scarce nesting observations in São Paulo (Silva \& Regalado 1998, Giorgetti \& Fonseca 2009).

King Vulture nests have been recorded in several sites, such as ground, rock walls, hollow dead trees and on emergent tree branches (Smith 1970, Ramo \& Busto 1988, Sick 1997, Silva \& Regalado 1998, Schlee 1995, 2000, Carvalho-Filho et al. 2004, Giorgetti \& Fonseca 2009). In this paper we report a nest on a manmade structure.

\section{Material and Methods}

The observations took place in the Estação Ecológica de Angatuba, Paranapanema river basin southwestern São Paulo state (Figure 1). This 1,394.15 ha ecological station preserves important remnants of Semideciduous Forest and Cerrado, housing emblematic species like Black Lion Tamarin Leontopithecus chrysopygus (Mikan, 1823) (Monteiro et al. 2009).

A wooden observation tower, known locally as "mirante", was installed at the station highest point, $822 \mathrm{~m}$ altitude, on a Semideciduous Forest stretch (23 $3^{\circ} 24^{\prime} 29^{\prime \prime} \mathrm{S}$ and $48^{\circ} 22^{\prime}$ '03' W). It has approximately $20 \mathrm{~m}$ high and its original function is to assist in early fire detection. We used a digital camera trap Tigrinus - Sony Cyber-Shot 14 megapixel to obtain the photograph.

\section{Results and Discussion}

On July 262012 a white egg was found on the tower at $11 \mathrm{~m}$ height (Figure 1). A week later, the camera trap was installed just ahead of the egg, about $1.5 \mathrm{~m}$ apart, and left for $6 \mathrm{~h}$. An adult was photographed next to the egg (Figure 2). On August 262012 the egg had disappeared and the adults did not return. Cuneo (1968) reports a 50 to 53 day incubation period. Only 30 days passed since our discovery, which we believed happened near the laying date due to frequent visits to area. The egg was probably preyed upon, predation of eggs and nestlings is a frequent cause of nest failure in vultures (Cuneo 1968, Sarasola et al. 2000).

This report represents the first documented record of this species for Estação Ecológica de Angatuba (Willis \& Oniki 2003, Monteiro et al. 2009, Centro... 2012, Wikiaves 2012). Among Cathartidae, use of manmade structures has also been reported for Black Vulture Coragyps atratus (Bechstein, 1793) (Hill III \& SchererNeto 1991, Vasconcelos 1997). Flexibility in choice of nesting sites

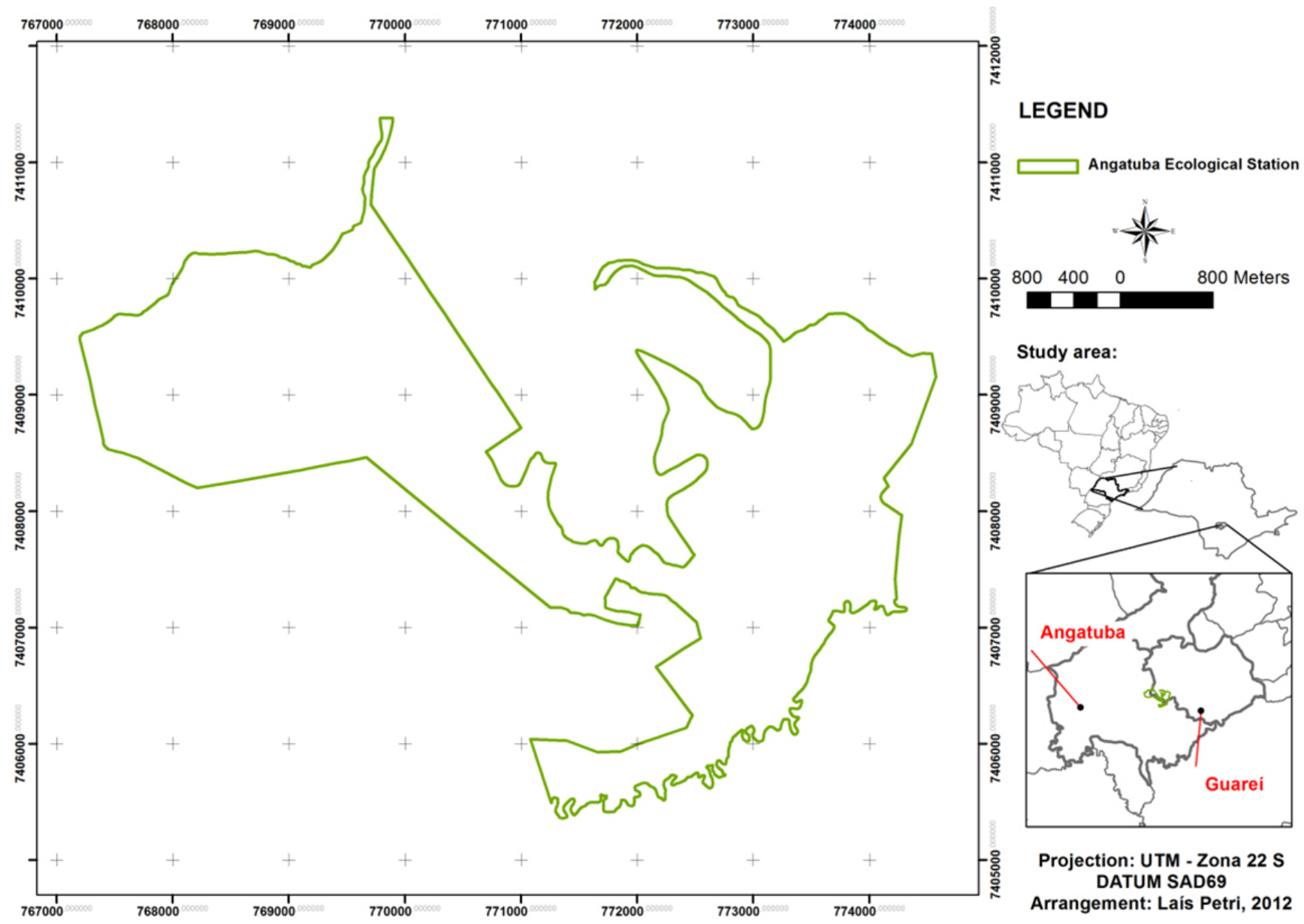

Figure 1. Location of Estação Ecológica de Angatuba, São Paulo, Brazil. 


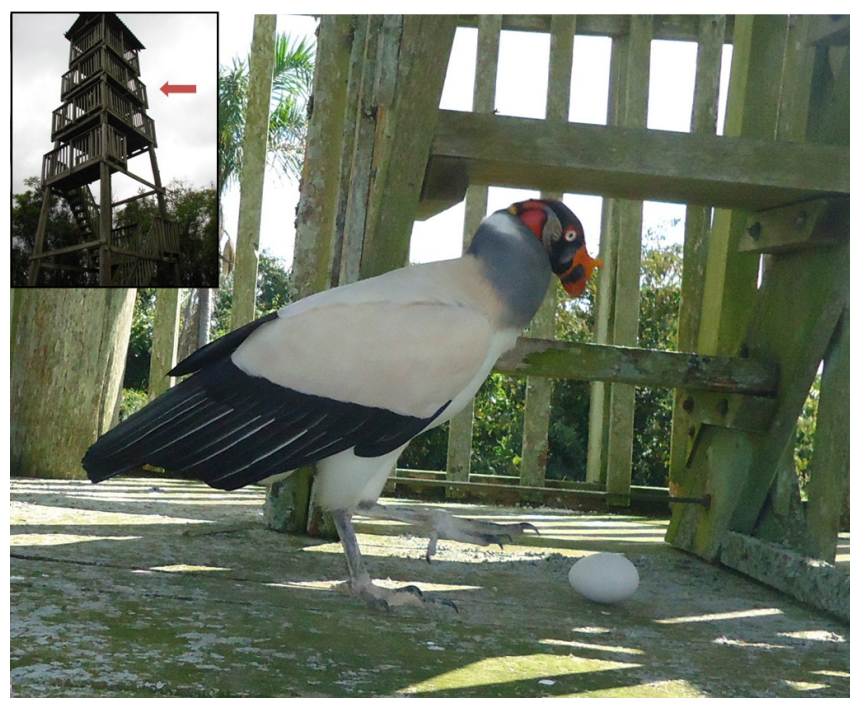

Figure 2. King Vulture (Sarcoramphus papa) with its egg. The inset shows the Estação Ecológica de Angatuba observation tower, with arrow indicating nesting site.

probably works as a pre-adaptation to use of certain buildings by vulture species.

Generally, reserve managers are aware of negative impacts that manmade structures can have on wildlife, for example collisions with window panes (Klem 2009). However, our report indicates the possibility that some of these structures can be used in order to favor certain species, including endangered ones. Researchers and other professionals associated with the management of protected areas should be aware of this possibility.

\section{Acknowledgments}

We thanks Estação Ecológica de Angatuba staff for their commitment and dedication, Angélica Midori Sugieda, Fundação Parque Zoológico de São Paulo, and two anonymous referees for valuable comments.

\section{References}

BIRDLIFE INTERNATIONAL. 2012. Sarcoramphus papa. In IUCN Red List ofThreatened Species (International Union for Conservation of Nature). version 2012.2. http://www.iucnredlist.org. (último acesso em 18/12/2012).

CARVALHO-FILHO, E.P.M., ZORZIN, G. \& SPECHT, G.V.A. 2004. Breeding biology of the King Vulture (Sarcoramphus papa) in southeastern Brazil. Ornitol. Neotrop. 15(2):219-224.
CENTRO DE ESTUDOS ORNITOLÓGICOS - CEO. 2012. Levantamento de avifauna em Unidades de Conservação do Estado de São Paulo. Estação Ecológica de Angatuba. http://www.ceo.org.br/avifest.htm (último acesso em 21/12/2012)

CUNEO, F. 1968. Notes on breeding the King vulture Sarcoramphus papa at Naples Zoo. Int. Zoo Yearbook 8(1):156-157. http://dx.doi. org/10.1111/j.1748-1090.1968.tb00471.x

GIORGETTI, M. \& FONSECA, R.C.B. 2009. Registro de urubu-rei (Sarcoramphus papa) em Cabrália Paulista, interior de São Paulo, Brasil. Naturalia 32:77-80.

HILL III, J.R. \& SCHERER-NETO, P. 1991. Black vultures nesting on sky scrapers in southern Brazil. J. Field Ornithol. 62(2):173-76.

KLEM, D.J.R. 2009. Preventing bird-window collisions. Wilson J. Ornithol. 121(2):314-321. http://dx.doi.org/10.1676/08-118.1

MONTEIRO, C.H., PRADO, B.H.S. \& DIAS, A.C. 2009. Plano de Manejo da Estação Ecológica de Angatuba. Instituto Florestal, SMA, São Paulo. http://www.iflorestal.sp.gov.br/Plano_de_manejo/eec_angatuba/ Plano_de_Manejo_EEc_Angatuba.pdf (último acesso em 18/12/2012).

RAMO, C. \& BUSTO, B. 1988. Observations at a King Vulture (Sarcoramphus papa) nest in Venezuela. Auk 105(1):195-196.

SÃO PAULO. Secretaria do Meio Ambiente. 2008. Decreto $n^{\circ}$ 53.494, de 2 de outubro de 2008. Diário Oficia do Estado de São Paulo, São Paulo, out. http://www.ambiente.sp.gov.br/wp-content/uploads/2011/10/ decreto_53494_0210081.pdf (último acesso em 18/12/2012).

SARASOLA, J.H., SOSA, R.A. \& MACEDA, J.J. 2000. A case of nest predation on Turkey Vultures nesting in Argentina. J. Raptor Res. 34(1):60-60.

SCHLEE, M.A. 1995. Nest records for the king vulture (Sarcoramphus papa) in Venezuela. J. Raptor Res. 29(4):269-272.

SCHLEE, M.A. 2000. Posthumous presentation of Carl B. Koford's manuscript on a nesting of the King Vulture Sarcoramphus papa on Barro Colorado Island. Vulture News 43:23-29.

SICK, H. 1997. Ornitologia Brasileira. Nova Fronteira, Rio de Janeiro.

SILVA, C. \& REGALADO, L.B. 1998. Nidificação em cavidade rochosa por urubu-rei Sarcoramphus papa (Falconiformes: Cathartidae) no Morro de Araçoiaba (Floresta Nacional de Ipanema - Iperó, São Paulo). Bol. CEO 13:4-8.

SMITH, N.G. 1970. Nesting of King Vulture and Black Hawk-eagle in Panama. Condor 72(2):247-248. http://dx.doi.org/10.2307/1366655

VASCONCELOS, M.F. 1997. Nidificações do urubu-de-cabeça-preta (Coragyps atratus) em um fosso profundo como uma provável defesa contra incêndios. Bios 5(5): 61-64.

WIKIAVES. 2012. A Enciclopédia das Aves do Brasil. http://www.wikiaves. com (último acesso em 20/12/2012).

WILLIS, E.O. \& ONIKI, Y. 2003. Aves do Estado de São Paulo. Divisa, Rio Claro. 